\title{
Design and Installation of Street Light for Public Lighting Business in Industrial 4.0
}

\author{
Firman Yudianto $^{1 *}$, Rizqi Putri Nourma Budiarti ${ }^{1}$ dan $^{\text {Zainatul Mufarikkoh }}{ }^{1}$ \\ ${ }^{1}$ Sistem Informasi, Fakultas Teknik, Universitas Nahdlatul Ulama Surabaya, Surabaya \\ *Corresponding Author \\ E-mail: firman@unusa.ac.id
}

\begin{abstract}
Industry development 4.0 makes every company always make continuous innovation so that it can provide satisfaction to each of its customers. In addition, it can increase the improvement in income obtained from the company. The aesthetics of the location of the company and the appearance of industrial sites will be able to attract customers to be able to increase the ordering of these industrial products. Calculation and installation of public street lighting around the location of the industry will be able to provide customer interest to come and be able to provide benefits to the company's production. The design and the installation of public street lighting will provide solutions for business feasibility in increasing revenue in the industrial era 4.0 by increasing financial and economic aspects.
\end{abstract}

Keywords: Public Street Lighting, Business, Financial Aspects, Industry 4.0.

\section{PENDAHULUAN}

The PT.X plastic packaging was company that first established in Bandung in 2001. The company is engaged in the packaging industry of plastic materials, especially packaging gallons of mineral water, cooking oil and so on. Along with the increasing demand from the market, in 2018 the company has expanded its production by building a new factory in the area of East Java Province, especially in location of Pasuruan Regency.

In the development of the construction of the factory, it is very necessary for a very adequate infrastructure, including the construction of public street lighting to the factory and the factory area and the addition of PLN electricity. To support infrastructure needs, PT. X has held an auction for the procurement of goods and services, which has been won by $\mathrm{CV}$. Indopratamas, which is domiciled in Malang, which is engaged in mechanical and electrical contractors. In terms of the owner and vendor, they pay attention to the technical and financial aspects so that on both sides no one is harmed, especially the location of the factory located in Pasuruan Regency. From here the owner is very concerned about the location of the plant, not to build this factory can bring adverse effects, especially for the surrounding community, on the contrary must have a positive impact, especially for the factory and the surrounding community [1,2,3]. For this reason, cooperation with the local district government is needed, including the construction of public street lighting infrastructure in the area leading to the factory [4,5]. 


\section{METODOLOGI}

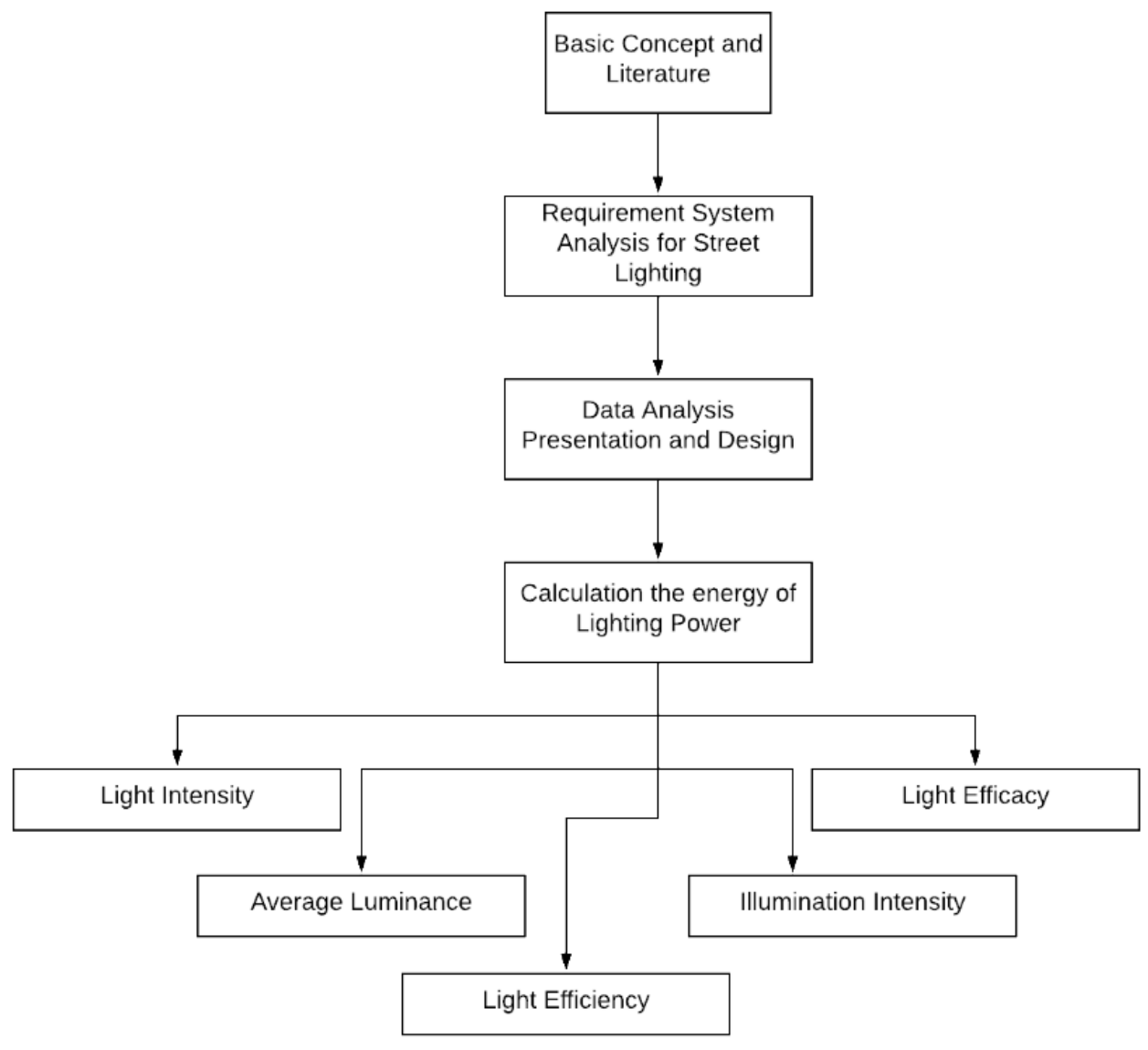

Figure 1. Research Methodology

\subsection{Basic Concepts of Street Light for Public Lighting}

Street lighting is a part of a complementary road that can be placed or placed on the left or right of the road and or in the middle (in the median part of the road) that is used to illuminate the road and the environment around the required road including intersection, overpass (interchange, overpass, fly over), bridges and underground roads (underpasses, tunnels).

Pena Garcia, Hurtado and Aguilar Luzon, used various methods in designing street lighting installations and encouraged engineers and researchers to discuss parameters such as light and color of light to be used as indicators of street lighting installations [5].

The intended lighting is a complete unit consisting of a light source (lamp / luminaire), optical elements (reflector / refector, refractor, diffuser). Electrical elements (connectors to the power source / power supply etc.), a supporting structure consisting of a supporting arm, a vertical truss and a lamppost foundation).

The international system information unit used is as follows:

a. Level / Strength of Illumination (Illumination - Lux), 
Defined as a number of light currents falling on a surface area of 1 (one) square meter as far as 1 (one) meter from a light source of 1 (one) lumen.

\section{b. Intensity Light,}

Defined as the current of light emitted by a source of light in one light cone, expressed in units of Candela.

\section{c. Lumination,}

Defined as the surface of an object that emits / reflects light intensity that appears in the unit surface area of the object, expressed in Candela per square meter $(\mathrm{Cd} / \mathrm{m} 2)$.

\section{d. Lumen}

Defined as a unit of measurement of the amount of light (light current).

\subsection{The requirement system for locating street lighting}

\subsubsection{The requirement system for street lighting}

The requirement system for locating street lighting is the arrangement of one lamp or arrangement of lights against another. The placement system has 2 (two) systems, namely:

a. Continuous Placement System

b. Continuous placement system is a system of placing continuous or continuous street lighting along a road or bridge.

c. Local (Local) Placement System

d. Partial placement system is a system of placing street lighting in a certain area or at a certain length of distance according to its needs.

\subsubsection{The types of lighting poles}

The types of lighting poles in terms of function and placement are divided into:

a. Rigid Lamp Supports

Rigid Lamp Stands are poles that are planned to be rigid / firm so that they are strong to withstand collisions. This pole placement is limited, except if there is enough free space or combined with a road safety building.

b. Easily Broken Lamp Support Poles

Easy Broken Light Support Pole is a pole that is planned if hit by it will not provide fatal damage. Placement of this pole is very wide because it can be placed in areas of narrow free space.

Table 1. Uniformity Ratio Comparison

\begin{tabular}{|c|c|}
\hline $\begin{array}{l}\text { PLACEMENT } \\
\text { LOCATION }\end{array}$ & $\begin{array}{l}\text { RAT } \\
\text { IO }\end{array}$ \\
\hline $\begin{array}{l}\text { 1. Traffic Lane } \\
\text { 3. in residential areas } \\
\text { 4. in commercial / } \\
\text { downtown areas }\end{array}$ & $6: 1$ \\
\hline $\begin{array}{l}\text { 2. Pedestrian path } \\
\text { a. in residential areas }\end{array}$ & $10: 1$ \\
\hline
\end{tabular}




\begin{tabular}{|l|l|}
\hline $\begin{array}{l}\text { b. in commercial / } \\
\text { downtown areas }\end{array}$ & $4: 1$ \\
\hline Tunnel & $4: 1$ \\
\hline Rest Area & $6: 1$ \\
\hline
\end{tabular}

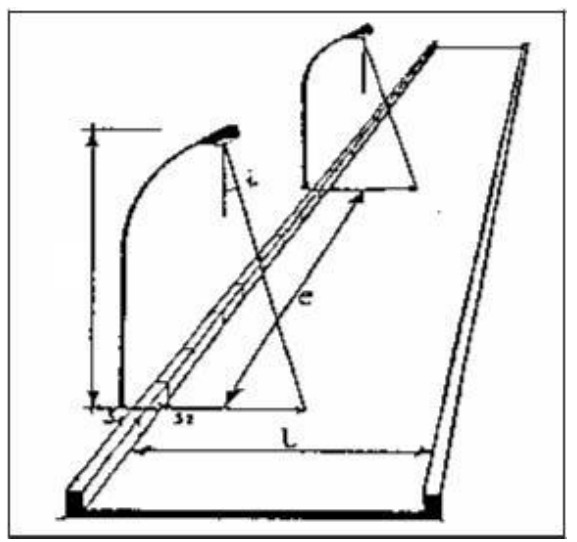

Figure 2. Placement of Public Street Lighting Lights

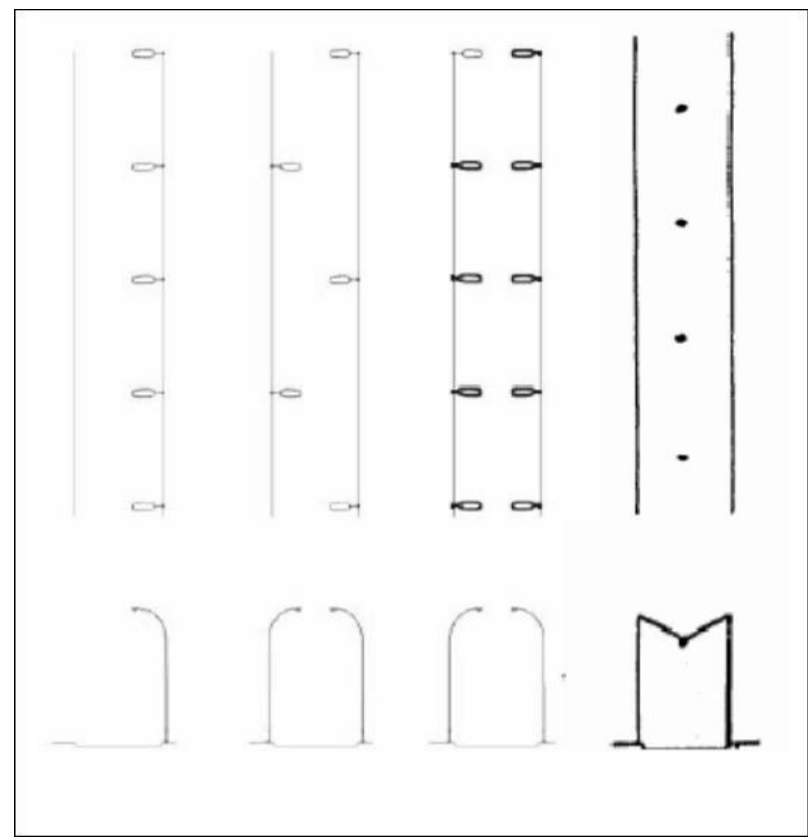

Figure 3. General description of lighting layout 


\subsection{Data Analysis Presentation and Design}

\subsubsection{Technical Analysis}

Technical analysis of work units and analysis of work unit prices are absolutely understood in the scope of LPJU's installation project activities. Especially for the parties involved in the procurement and implementation process of the project. With these two analyzes, the provider of goods or construction services can estimate the cost requirements, which are needed to carry out a type of work item. Estimated costs made by the users of construction goods or services are called owner estimate (OE), or it can be called a self-esteem price (HPS). The estimated cost made by the supplier of goods or services is called an estimator $(\mathrm{EE})$.

On the LPJU development work on the technical side is the design of LPJU composition which includes the determination of the number of lights, construction of poles, number of poles, conductive cables and safety systems. The number of lights also relates to the power of the lamp to be used. The number of lights greatly affects the intensity of the light produced which will ultimately affect the road coverage area. Calculations on technical aspects are based on the applicable Indonesian National Standard (SNI) and are listed on PUIL (General Requirements for Electrical Installation). Technical analysis needs to be done so that lighting can be generated optimally and the use of electric power is used appropriately and there is no waste.

On the LPJ development work on the technical side is the design of LPJ composition, the construction of poles, number of poles, conductive cables and safety systems. The number of lights is also used for the lamp to be used. The number of lights greatly affects the light produced which will ultimately affect the road coverage area. Calculations on Indonesian National Standard (SNI) and are listed on PUIL (General Requirements for Electrical Installation). Technical analysis needs to be done so that lighting can be generated optimally and the use of electric power is used appropriately and there is no waste.

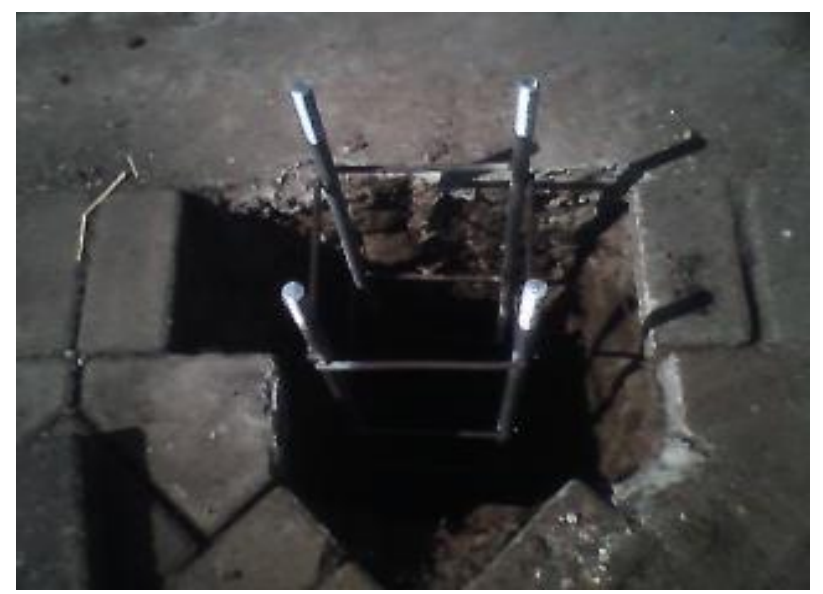

(a) 


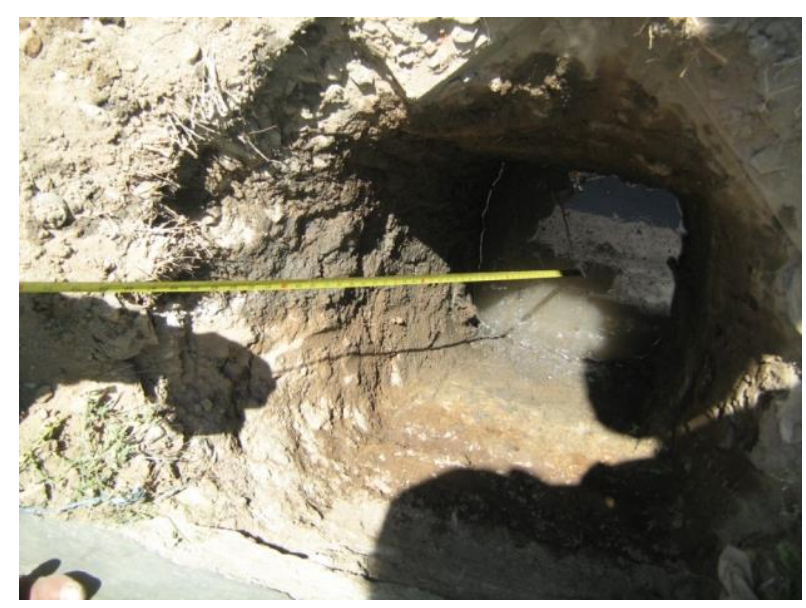

(b)

Figure 4. (a) and (b) are Field technical analysis of PJU foundation installation.

\subsection{Calculation the energy of Lighting Power.}

For roads with a width of 6 meters the author determines the type of high pressure sodium lamp. With a choice of 150 Watt SON-T power to be installed on a single arm pole. The choice of the type and quality of street lighting lamps is based on the value of efficiency, the age of the plan and the contrast of road surface and objects. straight path.

The use of ballasts and other electronic devices results in the absorption of electricity resources exceeding the power of the lamp itself. The SON-T $150 \mathrm{Watt}$ lamp has a voltage of $220 \mathrm{~V}$ with the total electric charge flowing is $0.8 \mathrm{~A}$. Then the electricity consumption is $220 * 0.8 \mathrm{VA}=176 \mathrm{Watts}$. The components of the lamp such as plastic require at least a little power to operate.

PJU lights must at least be able to operate from 6:00 a.m. to 6:00 a.m. with an operating time interval of around 12 hours. To be able to operate automatically the PJU lights have sensors to detect sunlight. So that when the sun's rays appear, the lights will automatically turn off.

The amount of energy used in SON T 150 lamps can be calculated as:

$$
\begin{aligned}
& E_{\text {load }}=P_{\text {load }} * \mathrm{t} \\
& E_{\text {load }}=150 * 12 \\
& \left.E_{\text {load }}=1800 \text { (watt.hour }\right)
\end{aligned}
$$

\subsubsection{Calculation of light intensity}

The calculation of the light intensity produced by LPJU can be searched using the following equation:

$$
\begin{aligned}
& \text { LPJU(150watt) } l=\frac{\emptyset}{w} \\
& \text { LPJU(150watt) } l=\frac{1800}{4 * 3,14} \\
& \text { LPJU(150watt) } l=1.194,3
\end{aligned}
$$

\subsubsection{Calculation of average luminance}

The average luminance calculation produced by LPJU can be searched using the formula: 


$$
\begin{aligned}
& \mathrm{L}_{\text {rata-rata }}=\frac{1}{A \cdot \emptyset} \\
& \mathrm{L}_{\text {rata-rata }}=\frac{1.194,3}{240 * \cos (60)} \\
& \mathrm{L}_{\text {rata-rata }}=9,95 \mathrm{~cd} / \mathrm{m}^{2} \\
& \mathrm{~L}_{\text {min }}=\frac{1}{\left(r^{2} \cdot \cos \emptyset\right)} \\
& \mathrm{L}_{\text {min }}=\frac{1194.3}{\left(\sqrt{8^{2}+16^{2}}\right)^{2} \cdot \frac{8}{\sqrt{\left(8^{2}+16^{2}\right)}}} \\
& \mathrm{L}_{\text {min }}=8.34 \mathrm{~cd} / \mathrm{m}^{2} \\
& \mathrm{~L}_{\text {max }}=\frac{1}{\left(r^{2} \cdot \cos \emptyset\right)} \\
& \mathrm{L}_{\text {max }}=\frac{1.194,3}{\left(8^{2} \cdot \cos 10\right)} \\
& \mathrm{L}_{\text {max }}=22,24 \mathrm{~cd} / \mathrm{m}^{2}
\end{aligned}
$$

\subsubsection{Calculation of light efficiency}

Calculation of light efficiency, using the formula:

$$
\begin{aligned}
& \text { LPJU } k=\frac{p \times l}{h(p+l)} \\
& k=\frac{25 \times 6}{8(25+6)} \\
& k=0.604 \\
& k_{\text {min }}=0.604 \\
& k_{\text {max }}=1.0 \\
& \eta=\eta_{\text {min }}+\frac{k-\mathrm{k}_{\text {min }}}{\mathrm{k}_{\max }-\mathrm{k}}\left(\eta_{\text {max }}-\eta_{\text {min }}\right) \\
& \eta=0.24+\frac{0.604-0.604}{1-0.604}(0.24-0.39) \\
& \eta=0.24 \\
& \eta=\eta_{\text {min }}+\frac{\theta_{\mathrm{g}}}{\theta_{0}} \text { fluks armatur, } \theta_{\mathrm{g}}=\eta \times \theta_{0} \\
& =0.24 \times 33000=7.9201 \text { luxmen }
\end{aligned}
$$




\subsubsection{Calculation of illumination intensity}

Calculation of conventional LPJU light efficiency using the formula:

$$
\begin{aligned}
& \mathrm{E}_{\text {rata-rata }}=\frac{\Theta}{A}=\frac{7920}{240}=33 \text { lux } \\
& \mathrm{E}_{\text {min }}=2 x \frac{\Theta g}{\mathrm{~h}^{2}} \cos ^{3} \bar{\alpha}=2 \times \frac{7920}{8^{2}}\left(\frac{8}{\sqrt{\left(8^{2}+16^{2}\right)}}\right)^{3}=22.13 \text { lux } \\
& \mathrm{E}_{\text {maks }}=\frac{\Theta g}{\mathrm{~h}^{2}} \cos ^{3} \bar{\alpha}=2 \mathrm{x} \frac{7920}{8^{2}} \cdot \cos ^{3} 10^{\circ}=146.2 \text { lux }
\end{aligned}
$$

\subsubsection{Calculation of light efficacy}

LLJU light efficacy calculations, use the following equation:

$$
\mathrm{K}=\frac{\Theta}{P}=\frac{18000}{150}=120 \mathrm{~lm} / \mathrm{watt}
$$

\section{RESEARCH RESULT AND DISCUSSION}

\subsection{Financial and Economic Aspects}

\subsubsection{Investment}

Fixed assets

a. Capital of Rp. 50,000,000

b. Land and office (Own) Rp. 30,000,000.00

c. Work equipment Rp. 20,000,000.00

d. Office equipment Rp. 3,000,000.00

e. Generator Rp. 5,000,000.00

f. Transport vehicles Rp. 62,000,000.00

Total Investment amount of Rp. 170,000,000.00

Table 2. Calculation of depreciation or depreciation.

\begin{tabular}{|c|r|r|r|}
\hline Year & \multicolumn{1}{|c|}{$\begin{array}{c}\text { Investment } \\
(\mathrm{Rp})\end{array}$} & $\begin{array}{c}\text { Depreciation } \\
(\%)\end{array}$ & $\begin{array}{c}\text { Depreciation } \\
(\mathrm{Rp} .)\end{array}$ \\
\hline 1 & $170,000,000.00$ & 50.00 & $85,000,000.00$ \\
\hline 2 & $85,000,000.00$ & 50.00 & $42,500,000.00$ \\
\hline 3 & $42,500,000.00$ & 50.00 & $21,250,000.00$ \\
\hline 4 & $21,250,000.00$ & 50.00 & $10,625,000.00$ \\
\hline 5 & $10,625,000.00$ & 50.00 & $5,312,500.00$ \\
\hline 6 & $5,312,500.00$ & 50.00 & $2,656,250.00$ \\
\hline 7 & $2,656,250.00$ & 50.00 & $1,328,125.00$ \\
\hline 8 & $1,328,125.00$ & 50.00 & $664,062.50$ \\
\hline
\end{tabular}

\subsubsection{Revenue Targets}

Profit and loss $=$ Rp.49,223,000-Rp.4,400,000

Profit and loss $=$ Rp. $44,823,000$

Calculation of Profitability Index (PI) 
Net cash receipts $=$ Average income yr $1+$ Value of investment after depreciation of 1 , the value of total profits is expressed

Total profit $(1$ year $)=12 \times$ Rp. $44,823,000$ gross profit $=$ IDR 49,223,000

\subsubsection{Estimated Costs and Profits}

Cost

Employee salary of Rp. 1,500,000.00

Transportation Rp. 1,600,000.00

Correspondence Rp. 300,000.00

Others Rp. 1,000,000.00

Total cost of Rp. 4,400,000.00

Profit and loss = Rp.49,223,000-Rp.4,400,000

Profit and loss $=$ Rp. $44,823,000$

Calculation of Profitability Index (PI)

Net cash receipts $=$ Average income yr $1+$ Value of investment after depreciation of 1 , the value of total profits is expressed

Total profit $(1$ year $)=12 \times$ Rp. $44,823,000$

\section{CONCLUTION}

From the technical analysis, it can be concluded that the construction of the PJU with the opposite type of road is very suitable to apply the PJU pole system with a single arm. With a road width of only 6 meters, the PJU pole with a height of 8 meters is enough to illuminate the road at night.

From financial analysis it can be concluded that the PJU development project at PT. Industry Company 4.0 that this project is feasible to do because based on the calculation of this project it is profitable for the contractor with a profitability index value of more than 1 ..

\section{REFERENCES}

[1] Baktiono Agus, "Kriteria Investasi”. 2016. Universitas Narotama. 2016.

[2] Dwi Febry Nurcahyo, “Analisis Kelayakan Bisnis”. Universitas Indonesia. 2017.

[3] Dede M Fathurrohman, "Analisis Kelayakan Investasi untuk Rencana Perluasan Jaringan PT Telkom Cabang Malang”, 2018, Universitas Muhammadiah Malang.

[4] Data Stat PLN, http://www.pln.co.id/dataweb/STAT/STAT2014IND.pdf has accessed on july 1,2019

[5] Pena-Garcia, A., Hurtado, A., \& Aguilar-Luzon, M.C. Impact of public lighting on pedestrians' perception of safety and well-being, Safety science. 78, pp. 142-148. 2015

[6] Siswanto Sutojo, "Studi Kelayakan Proyek", Konsep, Teknik \& Kasus.

[7] Kasmir and Jakfar. "Studi Kelayakan Bisnis". Ed.Revision., 2015, Jakarta: Kencana Prenada Media.

[8] H. Zainal, Z. Abidin., S. Husein, R. Umar., “Analisa Pembangkit Listrik Tenaga Surya Pulau Balang lompo”. Jurnal Listrik Telekomunikasi Elektronika. 2017.

[9] Kasmir and Jakfar, "Studi Kelayakan Bisnis" First Ed., 2012, Jakarta: Kencana. 